\title{
Parasites Identification and Histopathology Changes on Blood Cookle (Anadara granosa Linnaeus, 1758)
}

\author{
Yuni Karnisa*, Desrina and Ita Widowati \\ Faculty of Fisheries and Marine Sciences, Diponegoro University \\ J. Prof. H. Soedarto, S.H. Tembalang Semarang, 50275 Indonesia \\ E-mail: yunikarnisa@gmail.com
}

\begin{abstract}
Blood cockle Anadara granosa is a popular sea food in Indonesia and potential for aquaculture. Currently, blood cockle aquaculture is at early stage, done by taking the larva from wild and raised them in the pond. Wild animal naturally carries parasites without outward clinical signs but can cause disease problem under aquaculture condition. This study aimed to identify parasites and histopathology changes in wild A. granosa. Blood cockles $(n=90)$ were randomly collected during 3 months at three stations in the coastal waters of Bedono (Station 1: the intertidal area of the edge near to the mangrove area, station 2: the center of intertidal area, station 3: the area near to the sea), a village located on North Java coast and supplied blood cockle larva to the area. Parasites examination was conducted in the laboratory by macroscopic (observation of clinical symptoms) for ectoparasites and microscopic (using a microscope) for endoparasites. Histopathology preparation was done by taking three cockles at each station and cutting tissue that includes gills, foot, gonads, digestive tract and mantle. Organs were fixed in a 10\% NBF solution, processed, mounted in paraffin and stained with hematoxylin and eosin. Parasites found were identified and the level of intensity and prevalence were calculated. There were three species of parasites found: Pinnotheres sp. (Intensity 1 ind/cockle; Prevalence: 3.33\%), Perkinsus sp. (Intensity: 9.3 cell/cockle; Prevalence: 37.03\%), Nematopsis sp. (Intensity: 4.25 cell/cockle; Prevalence: 29.62\%). There were no histopathology changes on infected tissues which may relate to low diversity, prevalence and intensity of parasites found in this study.
\end{abstract}

Keywords: bivalvia, parasitic infestation, intensity, prevalence, Central Java

\section{Introduction}

Anadara granosa (Linnaeus, 1978) or commonly refers as blood cockle is abundance in protected estuary areas, especially areas with mangrove vegetation and smooth muddy. Geographical distribution of blood cockle includes Australia, Vietnam, China, Hong Kong, Thailand, Philipines, New Caledonia, Japan and Indonesia (Afiati, 2007; Suwanjarat et al., 2009; Santoso et al., 2015; Salaenoi et al., 2015, Khalil et al., 2017 and Zarkasi et al., 2018). Blood cockles has high economic potential with selling price reach IDR 20,000-30.000/kg in local market. Nowadays, the blood cockle in the market mostly comes from nature. Blood cockle aquaculture is still at early stage, done by taking wild blood cockle larva and raised them in brackish water ponds until reach market size. Excessive exploitation of blood cockle threated the natural population. To reduce pressure on the wild population can be done by cultivating. The cultivation of blood cockle started from the choose the broodstock candidate of good qualities, based on morphology, physiology, genetics and health condition.

Parasites of blood cockle taken from the nature need to be determine before cultivation activities to prevent the transmission of parasites to culture system. Parasites can inhibit growth even cause death on shells (Coen and Bishop, 2015). Some parasites that has been reported in the shells include Perkinsus chesapeaki on Cerastoderma edule (Carasso et al., 2014), Pinnotheres sp. at Anadara antiquata, A. granosa (Afiati, 2002) and Donax faba (Tenjing, 2017). Coastal water of Bedono village. Demak is one of the sources of blood cockle sold in the local market. Therefore, it is necessary to study the health of blood cockle in Bedono water.

This study was conducted to determine the presence of parasitic in blood cockle from nature, identifying the histopathology changes associated with parasites, and calculates the intensity and prevalence of parasites found. The results of this study are expected to provide information on 
parasites that can infect blood cockle ( $A$. granosa) as a first step in the efforts cultivating of blood cockles.

\section{Materials and Methods}

\section{Sampling location}

Bedono is a village in Sayung district, Demak, Central Java that has experienced severe abrasion. The waters are characterized by sandy mud deposits with relatively murky water. Along the line beach there are mangrove plants as an effort to prevent coastal erosion. Some residents of local communities are the collector of cockle for retail sale. Sampling was carried out on three stations (Figure 1.). Parasitic examination conducted at the Department of Aquaculture Laboratory, Diponegoro University.

\section{Sampling techniques}

This sampling was conducted monthly for three months (December 2018 to February 2019). Blood cockle samples $(n=90)$ were hand-picked (taken by hand), stored in the coolbox (lining with ice in plastic bag put separating from cockles by styrofoam) and taken to the laboratory for observation. The travel time from the sampling location to the laboratory was 1 hour. Measurement of water quality (salinity, dissolved oxygen, $\mathrm{pH}$, temperature) was measured in situ on every sampling.

\section{Morphophometric measurement}

The morphometry measurement of cockles included shell length, height and thickness. These were measured using a Vernier caliper $(0.05 \mu \mathrm{m})$ (Poutiers, 1998). The shell length started from the anterior to posterior. The shell width was measured from dorsal to ventral side. The shell thickness was measured from the case thick in a closed position (Gimin et al., 2004).

\section{Parasitic and histopathology observation}

Firstly, the parasites examination began with a macroscopic (gross pathology) clinical observation of the shell. The shell was opened by disconnecting the cockle abductor and the internal organs (gills, foot, gonads, gastrointestinal tract, mantle) was examined with naked eyes. Post mortem parasites observations are observed in each organ. Identification of parasites was conducted while alive (in fresh tissues) and in histological preparations afterward, counted for point prevalence and intensity.

Three cockles from each station per month $(n=27)$ were randomly selected for histopathology observation. The histological methods were conducted according to modified methods of
Histological Techniques for Marine Bivalve Mollusks by Howard (1983). Briefly, soft tissues were cut from dorsal to ventral in $5 \mathrm{~mm}$ thick and fixed in a $10 \%$ Neutral Buffer Formalin (NBF) solution for 24 hours. Tissue was dehydrated and processed according to histological techniques. The tissue already embedded in paraffin was cut $5 \mu \mathrm{m}$ thick and stained with Hematoxylin and Eosin (Howard et al., 2004). Slices containing gill parts, foot, gonads, digestive tract and mantle of each specimen were evaluated under a microscope from a low magnification $(40 x)$ to the highest magnification (1000x) and photographed. Identification of parasites refered to books "The Biology of Animal Parasites" (Noble et al., 1989), journal of Elston et al. (2003), Ermaitis (1984), Tuntiwaranuruk et al. (2004), Dang et al. (2015) and Becker (2010). The formula used for the calculation of intensity and prevalence values (Kim et al., 2006) was as follows:

Intensity (Ind/legs) $=\frac{\sum \text { individual parasites }}{\sum \text { Infected cockle samples }}$

Prevalence $(\%)=\frac{\sum \text { Infected cockle samples }}{\sum \text { observed cockle samples }} \times 100 \%$

\section{Results and Discussion}

\section{Parasite Anadara granosa and histopatholgy}

There were three species of parasites found, namely Pinnotheres sp., Perkinsus sp. and Nematopsis sp. Parasite Pinnotheres sp. was a group of crab Brachyuran (Decapoda, Pinnotheridae) found through macroscopic observation in blood cockles with shells length $>3 \mathrm{~cm}$. The range of the crab carapace length was $8-12 \mathrm{~mm}$.

Pinnotheres sp. or "Pea Crab", is a member of the family Pinnotheridae. It lives in symbiotic with invertebrates as the place of residence, shelter to avoiding predation and feed on the cockle tissues (Becker, 2010). Pinnotheres sp. was found only on the cavity of $A$. granosa in a living state. Pinnotheres $\mathrm{sp}$. was found in female $(n=2)$ and male cockle $(n=1)$ in very low number (1 pea crab/cockle) (Figure 2). The presence of Pinnotheres $\mathrm{sp}$. in this study macroscopically did not cause damage on the cavity of the mantle blood cockle but the gills. The male pea crab is a commensal while the females are parasitic (Afiati, 2002). These parasites have a structure called cheliped to take food from the gills. Consequently, its affected the structure of blood cockle gills as seen in this study.

Perkinsus is a genus of Alveolate in the phylum Perkinsozoa. The parasite Perkinsus sp. was found in the histology preparation of $A$. granosa (Figure 3). Perkinsus sp. was found in many 

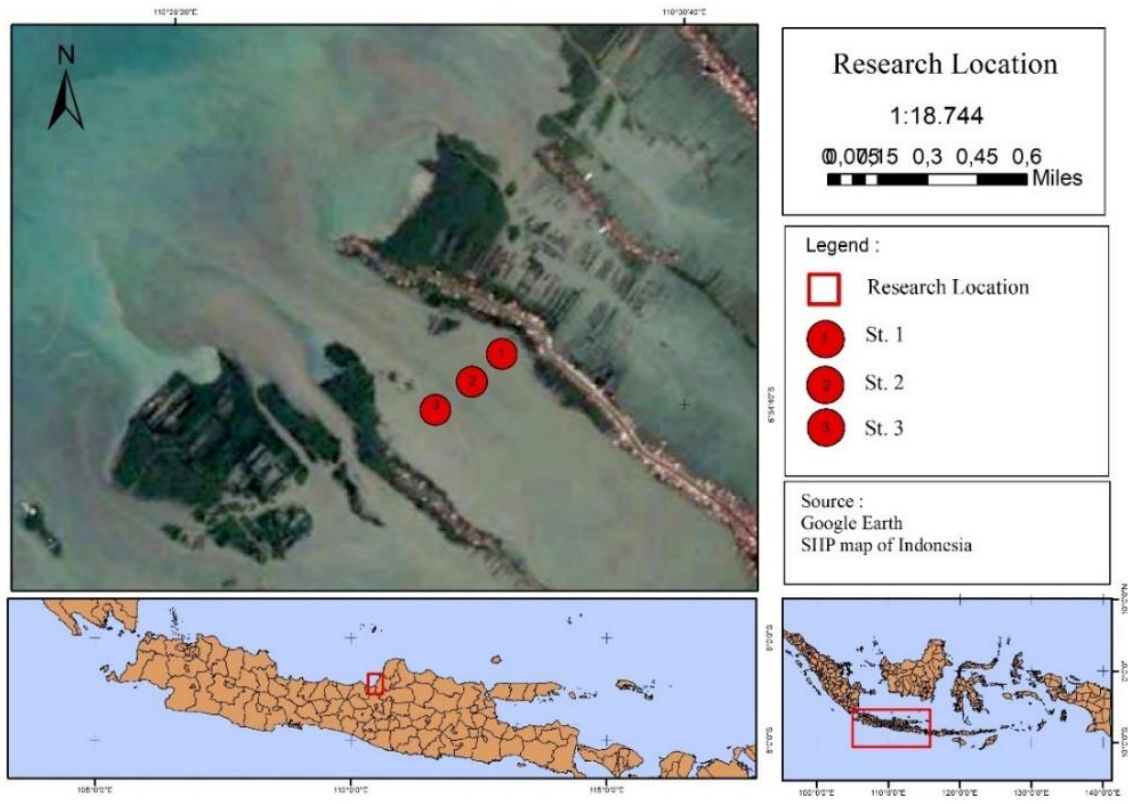

Figure 1. Sampling location in Bedono, Central Java

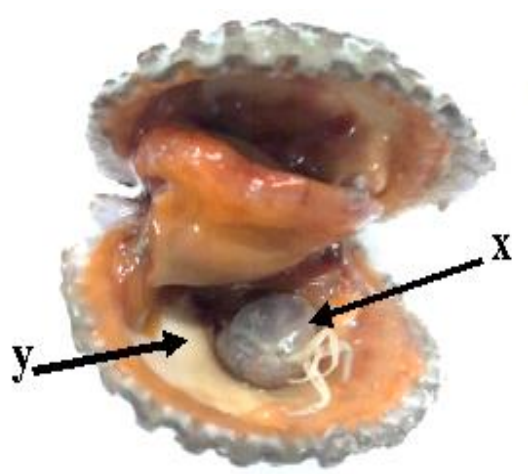

(a)

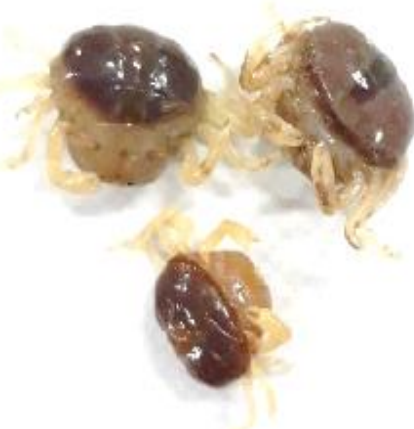

(b)

Figure 2. Parasite infestations of Pinnotheres sp. ( $\mathrm{x}$ ) on a mantle cavity (y) A. granosa (A) and three parasites of Pinnotheres sp. found in 3 blood shell samples (B).

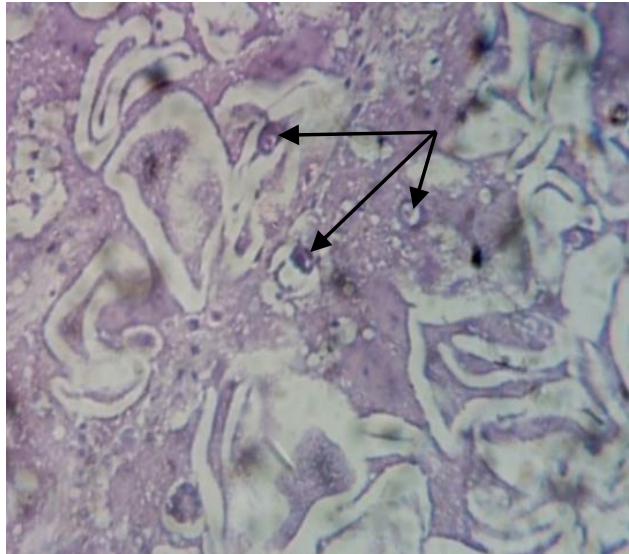

(a)

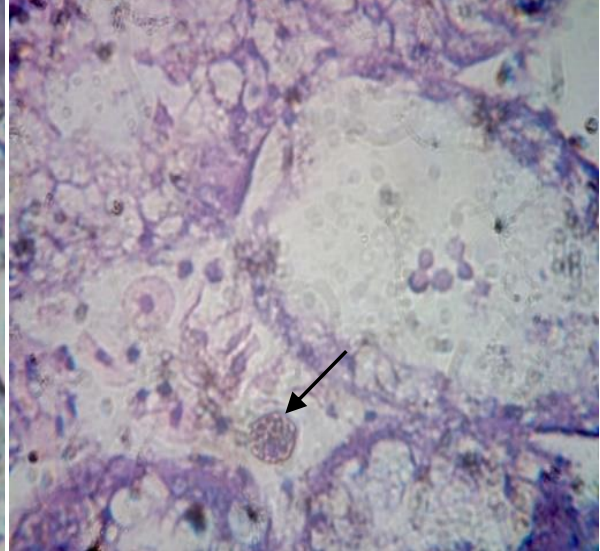

(b)

Figure 3. A. granosa infected parasitic Perkinsus sp. (a) showed infection Perkinsus sp. (Pe) in the network of gonads and (b) in the digestive gland, showing an infiltration of hemocytes possibly phagocytizing trophozoites (arrows). Hematoxyllin and Eosin. Magnification (A and B) x 400. 
epithelium of the digestive glands and was a small part found in the mantle blood cockle. The macroscopic clinical symptoms associated with Perkinsus sp. in this study were pale, wrinkle mantle, while the uninfected shells had bright colors. The trophozoite of Perkinsus sp. was detected in female cockle gonads and digestive epithelium. Trophozoite was spherical, with vacuoles occupying most of the cytoplasm (Figure 3). No damage or infiltration of hemocytes was seen in tissues infected by pathogens. Perkinsus sp. is a protozoan parasite that common to infects mollusks. Similar types of parasites have also been reported by Moss et al., 2008 on the oyster samples of Cassostrea hongkongensis infected by Perkinsus sp.

The presence of Perkinsus sp. caused a shell sligthly lose and did not close perfectly and had excessive mucous. Baker et al. (2007) reported other clinical signs were blisters on the inner skin surface, excessive production of mucus, the color of the flesh changed to pale and there was a wound on the mantle. However, only a few of clinical signs was observed in this study may be because of the light infection. Moss et al. (2008), explained that histologically the trophozoites in the infected tissues were round, has a nucleus which usually also contains prominent nucleoli, as well as large vacuoles. In infected oyster, the most intensely infected organ was the intestines and stomach. In addition, it also infected the digestive gland and esophageal tubules. Brandao et al. (2013) found parasitized cells on oysters (Crassostrea rhizophorae) especially in the digestive epithelium of the stomach and intestines, which may serve as a barrier to preventing parasites from dispersing. However, despite the prevalence and intensity of Perkinsus sp. observed high, oyster samples showed very little tissue damage. Dantas-Neto et al. (2015) in his research in Brazil also found no damage or hemocyte infiltration detected in tissues infected by the pathogen Perkinsus sp.

Parasite Nematopsis sp. (Family Porosporidae) was found in fresh and histological preparation of $A$. granosa. The process of invasion nematopsis $\mathrm{sp}$. shows different hosts between crustacean and Pelecypods marine. Soto et al., 1996; Estevez et al., 1998 reported that Gymnospores freed from crustaceans upon getting in the gills and mantle of susceptible bivalves by host phagocytes where they unfold to naked sporozoites (Porospora) or monozoic oocyst having thick hyaline wall enclosing a vermiform sporozoite. By the time of sporozoites or oocyst are swallowed by decapod definitive host, the life-cycle will be completed. Gymnospores released from crustaceans upon entering the gills and mantle of susceptible bivalves are engulfed by host phagocytes where they develop to naked sporozoites (Porospora) or monozoic oocyst having thick hyaline wall enclosing a vermiform sporozoite (Nematopsis). No multiplicative stage occurs in bivalves.

Life-cycle is completed when these naked sporozoites or oocysts are ingested by decapod definitive hosts (Soto et al., 1996; Estevez et al., 1998). Gymnospores released from crustaceans upon entering the gills and mantle of susceptible bivalves are engulfed by host phagocytes where they develop to naked sporozoites (Porospora) or monozoic oocyst having thick hyaline wall enclosing a vermiform sporozoite (Nematopsis).

Neatopsis sp. was found in many digestive glands, followed by gonads and the mantle of blood cockle. Uddin et al. (2011) reported parasite Nematopsis sp. most commonly observed in connective tissues adjacent to the epithelium of the intestinal tract. Histology sample examination of blood cockle showed an ellips oocytes with thick hyaline walls as a characteristic of Nematopsis sp. (Figure 4.). The number of oocytes consisted of two to five cells. The oocytes observed on connective tissues of the digestive and gastric glands.

\section{Intensity and prevalence of parasites}

The intensity and prevalence of various parasites in cockle samples collected from three stations over three months of research was presented in Table 1 . There is no temporal and spatial variation in the prevalence and intensity of parasites found (data not shown). Tuntiwaranuruk et al., 2004 was reported generally high infection in those months corresponding to the northeast monsoon season (November to February), which is characterized by low surface seawater temperature, high salinity, and low rainfall. The levels of infections decreased during the southwest monsoon season (March to October), which is characterized by higher surface seawater temperature, lower salinity, and high levels of rainfall.

The highest intensity of parasite infections caused by parasite Perkinsus sp., followed by Nematopsis sp. and Pinnotheres sp., Pinnotheres sp. (Figure 2). intensity was as low as of 1 ind/cockle and a prevalence of $3.33 \%$. Afiati (2002), found the same parasite at Anadara antiquata amounted to 241 out of 5254 pea crab or prevalence $4.59 \%$. The difference could be attributed to difference in cockle species, sampling site and sampling time. Water conditions such as temperature, salinity and rainfall intensity can also affect the presence of parasites. Tuntiwaranuruk et al. (2008) was found high parasitic prevalence on Perna viridis during low 

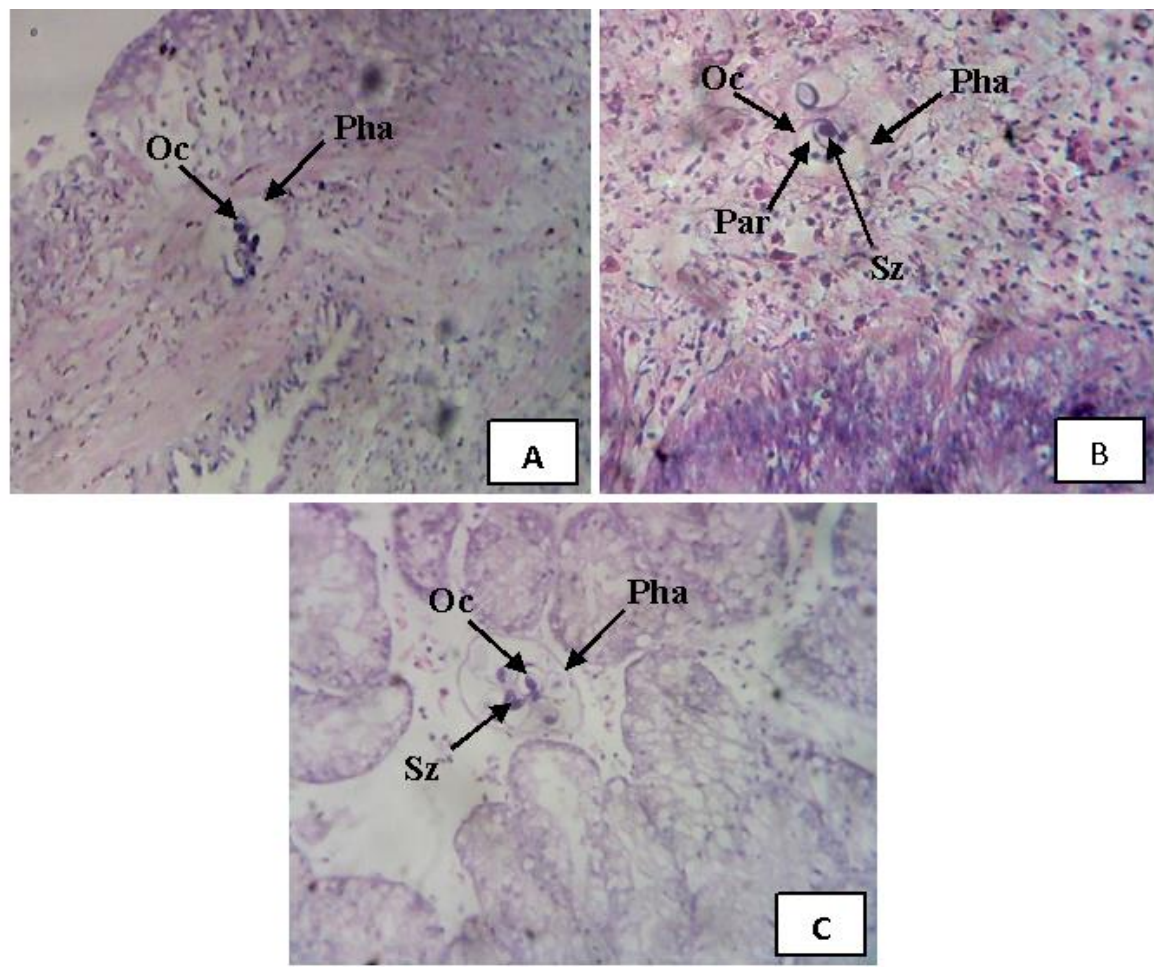

Figure 4. Histologyl observation of $A$. granosa on the mantle $(A)$, connective tissue in the intestines (B) and between the digestive epithelium (C) of $A$. granosa infected with Nematopsis sp. The image showed Phagocytes (Pha) containing Oocytes (Oc), as well as vacuoles Parasitophorus (Par) and sporozoite (Sz). Hematoxyllin and Eosin. Magnification $(\mathrm{A}, \mathrm{B}, \mathrm{C}) \times 400$.

Table 1. The intensity and prevalence of parasites in A. granosa

\begin{tabular}{cccccc}
\hline Parasites & \multirow{2}{*}{ Parasites } & $\Sigma$ Infected samples & $\sum$ Observed samples & $\begin{array}{c}\text { Intensity } \\
\text { (ind.cockle-1a, cell.cockle-1b) }\end{array}$ & Prevalence (\%) \\
\hline Pinnotheres sp. & 3 & 3 & 90 & $1^{\text {a }}$ & 3.33 \\
Perkinsus sp. & 93 & 10 & 27 & $9.3^{\mathrm{b}}$ & 37.03 \\
Nematopsis sp. & 34 & 8 & 27 & $4.25^{\mathrm{b}}$ & 29.62 \\
\hline
\end{tabular}

water temperature, high salinity and low rainfall. Due to low prevalence and low intensity, there was no clearly negative effect of pea crab infestation to the blood cockle in this study. However, another study suggested pea crab can cause significant effect on host conditions, i.e. decreased condition index by $12.7 \%$ and $15.9 \%$ in infected crabs (Pérez-Miguel et al., 2018).

The prevalence of Perkinsus sp. (Figure 3.) on A. granosa in this study reached $37.03 \%$, it found by histology analysis and showed the parasites in gonad, digestive tract and mantle with an intensity of 9.3 cells/cockle (Table 2.).

Although the observed Perkinsus sp. prevalence and intensity on $A$. granosa showed very little tissue damage. The parasites mostly found in digestive gland which probably function as barrier to prevent the parasites from dispering. This value was lower than it was reported by Luz et al. (2018). Study by Luz et al. (2018) found the prevalence of Perkinsus beihaiensis on Oyster in Brazil which reached $82,8 \%$ by histology observation and $65,2 \%$ by Ray's Fluid Thioglycollate Medium (RFTM) mainly in the gastric epithelium.

The prevalence of Nematopsis sp. on $A$. granosa was $29.62 \%$ with an intensity of 4.5 cells/cockle. No tissue damage was seen due to infection of this type of parasitic. The same parasite was also found on the Anadara granosa samples in the Straits of Malacca with a prevalence of 1.5-60\%. Although the prevelence reaches $99 \%$, there are no significant effects occurring on health (Kua et al., 2013). Whereas Suja et al. (2006) stated that Crassostrea madrasensis that are infected by nematopsis indicates hypertrophy in the infected 
Table 2. Microhabitat based parasites

\begin{tabular}{lccccc}
\hline \multicolumn{5}{c}{ Average number of parasites in organs } \\
\hline \multicolumn{1}{c}{ Parasite } & Giils & Foot & Gonads & Digestive tract & Mantle \\
\hline Pinnotheres sp. ${ }^{\mathrm{a}}$ & $0 \pm 0$ & $0 \pm 0$ & $0 \pm 0$ & $0 \pm 0$ & $0.0333 \pm 0.1805$ \\
Perkinsus sp. $^{\mathrm{b}}$ & $0 \pm 0$ & $0 \pm 0$ & $0.9629 \pm 3.2163$ & $3.5555 \pm 8.0543$ & $0.0740 \pm 0.3849$ \\
Nematopsis sp. $^{\mathrm{b}}$ & $0 \pm 0$ & $0 \pm 0$ & $0.2962 \pm 0.8688$ & $1.2592 \pm 2.5808$ & $0.1851 \pm 0.96225$ \\
\hline
\end{tabular}

$\mathrm{a} ; \mathrm{n}=90 ; \mathrm{b} ; \mathrm{n}=27$

Table 3. Water condition in sampling location of Bedono Village, Demak

\begin{tabular}{lccccccccccc}
\hline \multirow{2}{*}{ Sea water parameters } & \multicolumn{4}{c}{ Station } & \multicolumn{4}{c}{ January } & \multicolumn{3}{c}{$\begin{array}{c}\text { Water quality standard for } \\
\text { marine biota * }\end{array}$} \\
\cline { 2 - 11 } & \multicolumn{3}{c}{ December } & S2 & S3 & S1 & S2 & S3 & S1 & S2 & S3 \\
\hline pH & 9 & 8 & 8 & 8 & 7 & 8 & 8 & 7 & 8 & $7-8$ \\
DO (mg/l) & 4 & 3.8 & 4 & 4,2 & 4 & 3.2 & 4,6 & 4,2 & 3,2 & $>5$ \\
Temperature (C) & 29 & 30 & 30 & 32 & 32 & 34 & 30 & 31 & 32 & Natural \\
Salinity (\%) & 19 & 25 & 26 & 18 & 20 & 22 & 21 & 22 & 23 & Natural \\
\hline
\end{tabular}

S: Station; (*Ministry of Environment of Indonesia)

cells. It causes mechanical disturbances in the process of physiology such as feeding and gas exchange.

\section{Water conditions}

Water quality observation was done to analyze quality of habitat feasibility in supporting the life of an aquatic organism. The water quality parameters at the research site is presented in Table 3. Water quality measurement results showed variation at each station and month of sampling. Variations found were due to differences characteristics off the research stations. Temperature is one of the factors affected the presence of parasites. An increased temperature to some extent can caused a negative impact on the host's immune response and it facilitating parasites to infect the host. As Malek and James were reported (2018), the intensity of the Perkinsus marinus infection in oysters (Cassostrea virginica) in the United States increases when the temperatures are more than $35^{\circ} \mathrm{C}$. In general, over all the value of water quality in Bedono Village (Table 3 ) was still in optimum condition for the life of organisms.

The status of a biota in a water is heavily influenced by the fluctuation of the aquatic environment in its habitat. The waters are ideally to meet the standards, both physically, chemically, and biology. The value of water quality that exceeds the maximum threshold for its designation can be said to be polluted waters (Hamuna et al., 2018). Changes in environmental conditions in a water will trigger negative impact on blood cockle but favorable condition for a parasitic disease agent to flourish. This is return will interfere with the growth of the blood cockle.

\section{Conclusion}

There were three species of parasites found in the $A$. granosa examined in Bedono, Demak: Pinnotheres sp., Perkinsus sp. and Nematopsis sp.. The most frequently infected blood cockle organ in this study is the gastrointestinal tract, followed by gonads and mantle.The presence of these parasites caused minimum tissue damage in $A$. granosa because of the intensity that is still relatively low and the water condition of Bedono village is still within the optimum limit for shellfish.

\section{Acknowledgment}

Thanks to the Directorate of Research and Community Service, the Ministry of Research and Technology Indonesia for funding this research through research grant 7/EI/KP.PTNBH/2019.

\section{References}

Afiati, N. 2002. Pea Crab Infestation in Anadara antiquata (L.) and Anadara granosa (L.) Bivalvia. Arcidae) from Central Java, Indonesia. International Symposium on Crustacean Fisheris 2002. Biology, Technology and Management, 20-21 August 2002, IPB Bogor. doi: 10.13140/RG.2.1.4586.8961.

Afiati, N. 2007. Gonad maturation of two intertidal blood clams Anadara granosa (L.) and Anadara antiquata (L) (Bivalvia: Arcidae) in Central Java. J. Coast. Develop., 10 (2): 105-113.

Baker, S., Petty, D., Francis-Floyd, R., Yanong, R. \& Sturmer, L., 2007. Introduction to Infectious 
Diseases in Hard Clams., Florida: University of Florida.

Brandão, R.P., Boehs, G., Sabry, R.C., Ceuta, L.O., Luz, M.D.S.A., Queiroga, F.R. \& da Silva, P.M. 2013. Perkinsus sp. Infecting Oyster Crassostrea rhizophorae (Guilding, 1828) on the Coast of Bahia, Brazil. J. Inverte. Pathol., 112: 138-141. doi: 10.1016/j.jip.2012.11.003.

Coen, L.D \& Bishop, M.J. 2015. The ecology, evolution, impacts and management of hostparasit interactions of marine molluscs. J. Inverte. Pathol., 131: 177-211. doi: 10.1016 /j.jip.2015.08.005.

Darriba, S., Iglesias, D., Ruiz, M., Rodriguez, R. \& López,C. 2010. Histological survey of symbionts and other conditions in razor clam Ensis arcuatus (Jeffreys, 1865) (Pharidae) of the coast of Galicia (NW Spain). J. Invertebr. Pathol, 104: 23-30. doi: 10.1016/j.jip.2009.12 .005.

Dantas-Neto, M.P., Sabry, R.C., Ferreira, L.P., Romão, L.S. and Maggioni, R., 2015. Perkinsus sp. infecting the oyster Crassostrea rhizophorae from estuaries of the septentrional Northeast, Brazil. Braz. J. Biol, 75(4): 1030-1034. doi: 10.1590/1519-6984.06314.

Estevez, J., Sot, M., Rodrigues, H. \& Arias, C. 1998. Histopathology of bivalves in the Ria de Vigo (Galicia, NW Spain) infected by Nematopsis sp. (Protozoa:Apicomplexa). Res. Rev. in Parasitol, 58(1): 63-65.

Gimin, R., Mohan, R., Thinh, L.V. \& Graffiths, A.D. 2004. The relationship of shell dimensions and shell volume to live weight and soft tissue weight in the mangrove clam, Polymesoda erosa (Solander, 1786) from northern Australia. NAGA, WorldFish Center Quarterly, 27(3-4): 3235.

Howard, D.W., Lewis, E.J., Keller, B.J. \& Smith, C.S.. 2004. Histological techniques for marine bivalve mollusks and crustaceans. In:NOAA Technical memorandum NOS NCCOS, Oxford, 5: 1-218.

Khalil, M., Yasin, Z. \& Hwai, T.S. 2017. Reproductive Biology of Blood Anadara granosa (Bivalvia: Arcidae) in the Northern Region of the Starit of Malacca. Ocean Sci. J., 52(1): 75-89. doi: 10.1007/s12601-017-0010-y.

Kim, Y., Powell, E.N. \& Ashton-Alcox, K.A. 2006. Histopathology analysis. In: Y. Kim, K. A. Ashton-Alcox \& E. N. Powell, editors.
Histological techniques for marine bivalve molluscs: Update. NOAA Tech. Mem. NOS NCCOS. 27: 19-52.

Malek, J.C. \& Byers, J.E. 2018. Responses of an Oyster Host (Cassostrea virginica) and its Protozoan Parasite (Perkinsus marinus) to Increasing Air Temperature. PeerJ, 6:e5046. doi: $10.7717 /$ peerj.5046.

Moss, J.A., Xiao, J., Dungan, C.F. \& Reecea, K.S. 2008. Description of Perkinsus beihaiensis $n$. sp., a new Perkinsus sp. Parasite in Oysters of Southern China. J. Eukaryot. Microbiol, 55(4): 117-130. doi: 10.1111/j.1550-7408.2008.00 314

Noble, E.R., Noble, G.A., Schad, G.A. \& Macinnes, A.J. 1989. The Biology of Animal Paraites. Parasitology $6^{\text {th }}$ Edition. Philadelphia, London.

Kua, B.C., Salleh M.T. \& Noraziah, M.R. 2013. A Case Study of Protozoan Parasit Gregarine Nematopsis spp. (Apicomplexa: Sporozoa) Infestation in Mangrove Oyster Crassostrea belcheri Imported from Thailand. Pertanika J. Trop. Agric. Sci. 36 (3): 217-224.

Luz, M.S.A., Carvalho, F.S., Oliveira, H.C. \& Boehs, G. 2018. Perkinsus beihaiensis (Perkinsozoa) in oysters of Bahia State, Brazil. Braz. J. Biol, 78(2):289-295. doi: 10.1590/1519-6984.070 16.

Pérez-Miguel, M., Cuesta, J.A., Navas, J.I., Raso, J.G. and Drake, P.,. 2018. The prevalence and effects of the African pea crab Afropinnotheres monodi on the condition of the mussel Mytilus galloprovincialis and the cockle Cerastoderma edule., Aquaculture: 491: 1-9. doi: 10.1016./j. aquaculture.2018.02.050.

Poutiers J.M. 1998. Bivalves (Acephala, Lamellibranchia, Pelecypoda), pp 123-362. in: Carpenter, K.E \& V.H. Niem. 1998. FAO Species identification guide for fishery purposes. The living marine resources of the Western Central Pacific 1. Seaweeds, Corals, Bivalves and Gastropods. Rome. 686 p.

Salaenoi, J., Sukudom, C., Wonsin, T. \& Sirisuay, S 2015. Sediment Quality in Cockle Culture and Non-Cultured Area at Bandon Bay, Thailand. Mar. Environ. Sci. 110-114p

Santoso, P, Marsoedi, Maftuch \& Susilo, E. 2015. Building strategy priority of blood cockle aquaculture development for conservation and welfare in Sub-district of Central Kupang, West Timor, Indonesia. J. Biodiv. Environ. Sci., 7(4): 34-42. 
Soto, M., Pascual, S., Rodriguez, H., Gestal, C., Abollo, E., Arias, C. \& Estévez, J. 1996. Nematopsis spp. Schneider. 1892 (Apicomplexa: Gregarinida) in bivalve mollusk off Ria De Vig (Galicia, NW Spain). Bull. Eur. Ass. Fish Pathol., 16(5): 157-160.

Suja, G., Kripa, V., Mohamed, K.S., Shamal, P. \& Sanil, N.K., 2016. Nematopsis sp. (Apicomplexa: Porosporidae) Infection in Crassostrea madrasensis and its Associated Histopathology. J. Mar. Biol, 58(1): 29-33. doi: 10.6024/jmbai. 2016.58.1.1890-04.

Suwanjarat, J., Pituksalee, C. \& Thongchai, S. 2009. Reproductive cycle of Anadara granosa at Pattani Bay and its relationship with metal concentrations in the sediments Songklanakarin. J. Sci. Technol., 31(5): 471479.

Tenjing, S.Y. 2017. Pea-crab (Pinnotheres sp.) as commensal inside the shells of edible wedge clams and their predators along southwest coast of India. J. Mar. Biol, 59(1): 59-66. doi: 10.6024/jmbai.2017.59.1.1912-09.

Tuntiwaranuruk, C., Chalermwat, K., Upatham, E.S., Kruatrachue, M. and Azevedo, C., 2004. Infestigation of Nematopsis spp. Oocyte in 7 Species of Bivalves from Chonburi Province, Gulf of Thailand. Diseas. Aqua. Organism, 58(1): 47-53.

Uddin, M.J., Yasin, Z., Khalil, M. \& Shau-Hwai, A.T., 2011. Parasite of Blood Cockle (Anadara granosa Linnaeus, 1758) from the Straits of Malacca. J. Shellfish Res., 30(3): 875-880.

Zarkasi, K.Z., Halim, M.A., Nazari, T.F. \& Daud, F. 2018. Metagenomic Data on Anadara granosa Associated Bacterial Communities Using Culture Dependent Approaches and 16S rRNA Sequencing. Data in Brief, 19: 14-19. doi: 10.1016/j.dib.2018.05.052. 